ISSN: 2231-3354

Received on: 11-05-2012

Revised on: 17-05-2012

Accepted on: 22-05-2012

DO: 10.7324/J APS.2012.2604

C.O. Ujowndu, L.A. Nwaogu, E.U. Ezeji, K.O. Igne Department of Biochemistry, F ederal U niversity of Technology, Owerri, Nigeria.

\section{F.N. Kalu}

Department of Biochemistry, Uni versity of Nigeria, N sukka, Nigeria.

\section{Management of Changes in Liver Chemistry in Male Rats Aattly Exposed to CrudePetrolerm Oil}

\author{
CO. Ujomundu, F.N Kalu, L.A. Nwaogu, E.U. Ezgi and K.O. Igve
}

Keywords: Hepatotoxicity, oxidative enzymes, crude oil, liver function enzymes, Gongronema latifolium.

\title{
INTRODUCTION
}

Crude oil contains significantly high amount of toxic chemicals which can cause a wide range of health effects in people and wildlife, depending on the level of exposure and susceptibility. The chemicals can impair normal growth and development through a variety of mechanisms. They can cause mutations that may lead to cancer and multi-generational birth defects. The polycyclic aromatic hydrocarbon content of crude consists of fused aromatic rings (Fetzer, 2000). Some are identified as carcinogens, mutagens, and teratogens, for example benzene (CDC, 1999). Exposure of humans and animals to these chemicals is increasing in terms of the environmental level and the different usage of crude oil (Patrick-Iwuanyanwu et al., 2011). Difference in exposure or contact will occur based on location, work, personal activities, age, diet, use of protective equipment and other factors. The toxic effect can be acute lethal, sub-lethal or both, depending on the level of exposure, organism exposed and the dosage it is exposed to ( Rothman et al., 1996).

\section{For Correspondence} C.O. Ujowndu, Department of Biochemistry, F ederal U niversity of Technology, Owerri, Nigeria. 
Gongronema latifolium is a commonly consumed spice in Nigeria with useful medicinal potential. It has high level of phytochemicals which confers it antibacterial, antitumour, anticancer and antidiabetic properties (Okafor et al., 1993; Zhejian et al., 2007). In Nigeria, especially in Niger Delta region this spice is used in the preparation of soups and stews and in herbal concoctions. Research studies have been carried out to determine the effects of crude oil on rats and catfish (Sunmonu \& Oloyede, 2006; 2007). But the authors have failed to utilize the plant resources abundant in our environment to ameliorate the toxicological impact of crude oil and its fractions.

This study was designed to investigate the biochemical and toxicological effect of readily available plant and plant product G. latifolium supplemented diet in the presence of crude oil induced intoxication.

\section{MATERIALS AND METHODS}

\section{Plant materials}

\section{Collection, identification and preparation of plant materials}

Gongronema latifolium leaves were purchased from Ekeonuwa Market in Owerri municipal council, Imo State, Nigeria. The plant was identified by Dr. A.C. Ibe, a plant taxonomist in the Department of Crop Science, Federal University of Technology Owerri, Nigeria. The fresh leaves were air dried in the laboratory, ground into powder and sieved. Powdered G. latifolium leaves were mixed with mashed rat feed (1:4 ratios) to obtain $25 \% G$. latifolium supplemented feed. The feed mixture was made into pellets and stored.

\section{Experimental animals and crude petroleum}

Healthy male albino rats (Rattus norvegicus) of 7-9 weeks old, with an average weight of $176.71 \pm 20.07 \mathrm{~g}$ were obtained from the Department of Veterinary Pathology and Microbiology, Faculty of Veterinary Medicine, University of Nigeria, Nsukka, Enugu State, Nigeria. The rats were kept in well ventilated steel cages under natural environmental conditions of temperature and 12 hours light/dark cycle. Rat feed and water was provided ad libitium. This study followed the guidelines on the care and well being of research animals (NIH, 1985) and was approved by the Ethical Committee of the Department of Biochemistry Federal University of Technology Owerri, Nigeria. Crude petroleum was obtained from a Nigerian National Petroleum Corporation (NNPC), refinery, Portharcourt, Rivers State, Nigeria. Rat feed was from Vital Poultry Growers Pellets (a product of Grand feed Nigeria Ltd.).

\section{Chemicals and Reagents}

Chemicals used in this study were of analytical grade. All reagents for the assays were commercial kits and products of Randox Laboratories Ltd, Antrim, United Kingdom, Biosystems S.A. Barcelona, Spain, and TECO Diagnostics, Anaheim, USA.

\section{Preliminary Study}

Preliminary toxicity study to determine the volume of crude oil that could cause toxicity was carried out using 15 healthy albino rats. Rats were divided into five groups of three rats per group and were treated orally with $1,2,4,6$, and $9 \mathrm{ml} / \mathrm{kg}$ body weight of crude oil respectively. The rats were observed over a 24 hour period for nervousness, dullness, weight loss, in-coordination and or death. Increased dullness and weight loss was observed with increased diesel intake and death occurred at $9 \mathrm{ml} / \mathrm{kg}$. From the range of doses used, $4 \mathrm{ml} / \mathrm{kg}$ was chosen for this study.

\section{Hepatoprotective study}

Eighteen male albino rats were grouped into three with each group containing six rats. They were allowed to acclimatize for two weeks. Oxidative stress was induced by administering (except control) $4 \mathrm{ml} / \mathrm{kg}$ body weight of crude oil orally, using a $3.5 \mathrm{~cm}$ feeding tube attached to a syringe. Crude oil was administered to the animals every other day for 7days. Animals were fed with supplemented diet as they received the crude oil (except control). Rats in group I served as control and they were fed control diet (Rat feed only) and not administered crude oil. Rats in group II served as test group and were administered crude oil and supplemented diet (25\% G. latifolium). Group III served as the untreated control and were administered crude oil and fed control diet.

\section{Blood Collection and Preparation of Liver Homogenate}

The animals were sacrificed after 24 hours fast on the eighth day. They were anaesthetized by dropping into a jar containing cotton wool soaked in chloroform. Blood was collected by cardiac puncture, allowed to coagulate at $37{ }^{\circ} \mathrm{C}$ for $30 \mathrm{~min}$ and serum separated by centrifugation at $2500 \mathrm{rpm}$ for $10 \mathrm{~min}$ and stored at $4{ }^{\circ} \mathrm{C}$. Liver tissues of rats were excised, weighed and some part homogenized in potassium chloride $(\mathrm{KCl})(10 \mathrm{mM})$ phosphate buffer $(1.15 \%)$ with Ethylenediamine tetra - acetic acid (EDTA; pH 7.4) and centrifuged at 12,000 x g for 60 minutes. The supernatant was used to assay for oxidative stress enzymes and compounds.

\section{Estimation of Liver function markers}

Serum albumin (ALB) was determined by the method of Doumas et al., (1971), serum total protein (TP) by the method of Tietz, (1995), serum bilirubin by colourimetric method based on the method described by Jendrassik and Grof, (1938), for the in vitro determinations in serum using Randox laboratory test kit (Antrim, UK). Globulin was calculated thus; serum globulin = total protein - serum albumin (TP-ALB).

The estimation of alanine aminotransaminase (ALT) and aspartate aminotransaminase (AST) activities was done using Reitman and Frankel, (1957) method for the quantitative in-vitro determinations in serum using Randox laboratory test Kit (Antrim, $\mathrm{UK})$. 


\section{Estimation of Serum Lipid Profile}

The estimation of serum cholesterol was done by the combined methods of Allain et al, (1974) and Meiattini et al., (1978); triglycerides by the combined methods of Bucolo and David (1973) and Fossati and principle (1982), high density lipoprotein (HDL) - cholesterol by the method of Lopes-virella et al, (1977), for the quantitative in-vitro determination of lipid concentration in serum using Biosystems test kit (Barcelona, Spain). Serum low density lipoprotein (LDL) - cholesterol and very low density lipoprotein (VLDL) - cholesterol were estimation thus: $\operatorname{VLDL}(\mathrm{mmol} / \mathrm{l})=$ Triglyceride $/ 2.2 ; \operatorname{LDL}(\mathrm{mMol} / \mathrm{l})=$ total cholesterol - triglycerides/2.2 - HDL

\section{Estimation of Oxidative Stress Makers}

Catalase activity was done according to the method of Aebi (1983), superoxide dismutase (SOD) by the method of Xin et al, (1991); glutathione (GSH) by the method of King and Wootton (1959); glutathione peroxidase (GPX) activity by the method of Paglia and Valentine (1967); Lipid peroxidation was estimated spectrophotometrically by measuring the concentration of the lipid peroxidation product - malondialdehyde (MDA) as described by Wallin et al, (1993).

\section{Data analysis}

Results are expressed as mean \pm standard deviation and all data were subjected to analysis of variance (ANOVA) as described by Steel and Torrie, (1960). Significant differences between the treatment means were detected at 5\% confidence level using Duncan's multiple range test (Duncan, 1955).

\section{RESULTS}

Table 1 presents the effects of crude oil and G. latifolium supplemented diet on Oxidative stress parameters. It shows a significant $(\mathrm{P}<0.05)$ effect of oral ingestion of crude petroleum on the activities of glutathione peroxidase (GPx), superoxide dismutase (SOD) and concentration of glutathione and malondialdehyde. Catalase activity decreased non-significantly. The result shows that rats (in group II) which consumed $G$. latifolium in the diet with the oral administration of crude oil expressed oxidative stress properties which are within those of the control animals (group I) which were maintained on the rat feed only.

The effect of crude petroleum and G. latifolium is shown in table 2. Animals administered crude petroleum only (group III) showed significant $(\mathrm{P}<0.05)$ increase in activities of serum hepatic enzymes, ALT and AST. Concentrations of total protein and globulin decreased significantly $(\mathrm{P}<0.05)$ and total bilirubin increased significantly in group III rats when compared to control rats. Serum albumin concentration was non-significantly affected. The values obtained from feeding rats with supplemented diet showed non-significant $(\mathrm{P}<0.05)$ change in AST and ALT activities and concentrations of albumin and total bilirubin, whereas concentrations of total protein and globulin decreased significantly when compared to control rats. Thus showing that G. latifolium maintained these serum hepatic parameters within normal.

Effect of oral administration crude oil and feeding with $G$. latifolium supplemented diet on lipid profile is shown in table 3. A general view of the values obtained showed that the lipid profile of rats were non-significantly $(\mathrm{P}<0.05)$ affected by any of the treatments. On group comparison only LDL-cholesterol was significantly increased in group III when compared to control (group I).

\section{DISCUSSION}

Studies have implicated free radicals from exogenous and indigenous sources in the etiology of a lot of degenerative diseases such as coronary artery diseases, stroke, rheumatoid arthritis, diabetes and cancer (Halliwell et al., 1992). In this study the significantly reduced activities of SOD and GPx and concentration of glutathione and MDA may have resulted from by hepatic injury from oxidative stress from crude petroleum oil exposure. The nonsignificant values obtained from rats fed with G. latifolium and when compared to control indicates antioxidative and hepatoprotective properties G. latifolium. The activity of catalase was not adversely affected by either the diesel or the treatment. The near normal activity of SOD and GPx in rats treated simultaneously with $G$. latifolium shows that the spice contains active principles that inhibit actions of oxygen free radicals (Demicheli et al., 2007). In system, tissue and organ damage, reduced glutathione (GSH) makes up the first line of defense against free radicals resulting from xenobiotic ingestion. The drop in the concentration of liver GSH and corresponding increase in concentration of malondialdehyde and decrease in activity of glutathione peroxidase indicates hepatocytes damage. G. latifolium fed rats showed significant increase in GSH activity, suggesting a possible effect on the de novo synthesis and or regeneration of GSH. Ko et al (1995) reported GSH homeostasis in the presence of increased radicals. Increased MDA indicates increased lipid peroxidation which could have resulted from depletion of GSH concentration. The maintenance of MDA concentration of treated rats close to the concentration of control rats implies that $G$. latifolium inhibited the oxidation of the thiol groups, thus preventing GSH depletion. This indicates antioxidative role of the G. latifolium in the supplemented diet. The consequence of the oxidative effect of diesel contamination was observed from the significant increase in activities of liver damage marker enzymes AST and ALT. This increase in activities of these enzymes indicated cellular leakage and failure of functional integrity of liver cell membranes (Mukherjere, 2003). The reduced activities of AST and ALT in rats fed supplemented diet suggest protective effect of G. latifolium. The active constituents of the plants may have caused a stabilization and repair of plasma membranes damaged by exposure to contamination (Thabrew et al., 1987).

The observed significant decrease in total protein and globulin concentrations in crude petroleum treated rats and the non-significant decrease in concentration of albumin in this study 
Table. 1: Effect of crude oil intoxication and G. latifolium supplemented diet on Oxidant parameters.

\begin{tabular}{|c|c|c|c|c|c|}
\hline & Catalase (IU/g tissue) & $\begin{array}{c}\text { Superoxide Dismutase } \\
\text { (IU/g tissue) }\end{array}$ & $\begin{array}{c}\text { Glutathione }(\mathrm{mg} / \mathrm{g} \\
\text { tissue) }\end{array}$ & $\begin{array}{c}\text { Glutathione Peroxidase } \\
\text { (IU/g tissue) }\end{array}$ & MDA (\% TBARS) \\
\hline Group I & $7.81 \pm 0.37^{\mathrm{a}}$ & $1.11 \pm 0.34^{\mathrm{a}}$ & $2.03 \pm 0.09^{\mathrm{a}}$ & $531.09 \pm 21.44^{\mathrm{a}}$ & $5.10 \pm 1.05^{\mathrm{a}}$ \\
\hline Group II & $8.06 \pm 0.25^{\mathrm{a}}$ & $1.11 \pm 0.06^{\mathrm{a}}$ & $1.73 \pm 0.23^{\mathrm{a}}$ & $427.35 \pm 84.91^{\mathrm{a}}$ & $3.75 \pm 0.25^{\mathrm{a}}$ \\
\hline Group III & $7.56 \pm 0.44^{\mathrm{a}}$ & $0.37 \pm 0.33^{\mathrm{b}}$ & $1.17 \pm 0.09^{\mathrm{b}}$ & $318.80 \pm 16.24^{b}$ & $7.08 \pm 0.80^{\mathrm{b}}$ \\
\hline F value & 1.47 & 9.484 & 24.39 & 12.78 & 13.97 \\
\hline$P$ value & 0.30 & 0.01 & 0.001 & 0.006 & 0.005 \\
\hline
\end{tabular}

Values are mean \pm Standard deviation. Values with different superscripts per column are significantly different $(\mathrm{P}<0.05)$.

Table. 2: Effect of crude oil intoxication and G. latifolium supplemented diet on Liver function parameters.

\begin{tabular}{|c|c|c|c|c|c|c|}
\hline & $\operatorname{Albumin}(\mathrm{g} / \mathrm{l})$ & Total protein $(\mathrm{g} / \mathrm{l})$ & Globulin $(\mu \mathrm{mol} / \mathrm{l})$ & Total Bilirubin (g/l) & ALT (IU/I) & AST (IU/I) \\
\hline Group I & $42.00 \pm 3.61^{\mathrm{a}}$ & $94.67 \pm 9.29^{\mathrm{a}}$ & $52.67 \pm 5.77^{\mathrm{a}}$ & $9.63 \pm 0.94^{\mathrm{a}}$ & $19.86 \pm 0.57^{\mathrm{a}}$ & $41.33 \pm 9.81^{\mathrm{a}}$ \\
\hline Group II & $40.33 \pm 1.24^{\mathrm{a}}$ & $72.00 \pm 5.58^{b}$ & $31.66 \pm 4.92^{\mathrm{b}}$ & $14.86 \pm 2.68^{\mathrm{ab}}$ & $21.80 \pm 1.47^{\mathrm{a}}$ & $63.66 \pm 11.67^{a}$ \\
\hline Group III & $42.33 \pm 2.62^{\mathrm{a}}$ & $73.00 \pm 3.56^{\mathrm{b}}$ & $30.66 \pm 2.4^{b}$ & $19.86 \pm 0.46^{\mathrm{b}}$ & $31.93 \pm 6.38^{\mathrm{b}}$ & $82.00 \pm 7.78^{\mathrm{b}}$ \\
\hline F value & 0.402 & 9.383 & 17.582 & 4.4604 & 5.84 & 9.531 \\
\hline $\mathrm{P}$ value & 0.685 & 0.014 & 0.003 & 0.061 & 0.038 & 0.013 \\
\hline
\end{tabular}

Values are mean \pm Standard deviation. Values with different superscripts per column are significantly different $(\mathrm{P}<0.05)$.

Table. 3: Effect of crude oil intoxication and G. latifolium supplemented diet on Liver Lipid Profile.

\begin{tabular}{|c|c|c|c|c|c|}
\hline 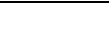 & Cholesterol (mMol/l) & Triglycerides (mMol/l) & VLDL (mMol/l) & HDL (mMol/l) & LDL (mMol/l) \\
\hline Group I & $1.20 \pm 0.36^{\mathrm{a}}$ & $1.10 \pm 0.36^{\mathrm{a}}$ & $0.50 \pm 0.18^{\mathrm{a}}$ & $0.50 \pm 0.10^{\mathrm{a}}$ & $0.20 \pm 0.14^{\mathrm{a}}$ \\
\hline Group II & $1.26 \pm 0.38^{\mathrm{a}}$ & $0.53 \pm 0.32^{\mathrm{a}}$ & $0.24 \pm 0.15^{\mathrm{a}}$ & $0.56 \pm 0.15^{\mathrm{a}}$ & $0.35 \pm 0.04^{\mathrm{a}}$ \\
\hline Group III & $1.36 \pm 0.49^{\mathrm{a}}$ & $0.87 \pm 0.21^{\mathrm{a}}$ & $0.38 \pm 0.10^{\mathrm{a}}$ & $0.60 \pm 0.10^{\mathrm{a}}$ & $0.41 \pm 0.12^{\mathrm{b}}$ \\
\hline $\mathrm{F}$ value & 0.694 & 2.63 & 2.31 & 0.538 & 3.05 \\
\hline $\mathrm{P}$ value & 0.535 & 0.150 & 0.180 & 0.609 & 0.121 \\
\hline
\end{tabular}

Values are mean \pm Standard deviation. Values with different superscripts per column are significantly different $(\mathrm{P}<0.05)$.

is in agreement with that obtained in similar studies when rats were exposed to crude oil (Sunmonu and Oloyede, 2007; Braid et al., 2011). In rats intoxicated with crude oil and fed supplemented albumin concentrations were maintained close to that of control. Concentration of total bilirubin increased significantly in exposed and untreated rats indicating inhibition of binding, conjugation and excretory capacity of hepatocytes (Mankani et al., 2005), because liver cells are responsible for removing bilirubin from serum (Nelson and Cox, 2005). However the non significant increase in total bilirubin concentration obtained in rats fed supplemented diet could be linked to the anti-hepatotoxic and liver protective ability of G. latifolium. Related reduction in bilirubin concentration on treatment with plant and plant products have been reported by Rosalinda et al. (2009) and Tsala et al. (2010). G. latifolium constituents may have protected the liver by enhancing bilirubin uptake and conjugation by the liver and subsequent secretion into the bile ducts.

The serum lipid profile (except LDL-cholesterol) of all the experimental groups did not show significant change. Fluctuations in lipid profile are very important in monitoring incidences of cardiovascular disorders. Serum concentrations of total cholesterol, triglycerides, LDL- cholesterol and HDLcholesterol are independent but are significant predictors of cardiovascular disease risk (Wilson, et al., 1998). A study by Brunzel et al., (2008) showed that increased concentration of LDLcholesterol signified oxidative stress. The significant increase in LDL-cholesterol concentrations observed in rats exposed to crude oil but not fed with supplemented diet emphasizes the observation of Brunzel et al., (2008). LDL-cholesterol concentration in rats fed G. latifolium supplemented diet did not cause a significant change compared to control rats. The observed values of lipids are in line with the work of Alisi et al., (2008), which reported a causual association between hypolipidemic potential and hepatoprotective effect. But Nwachukwu and Ibeh (2009) have reported hypolipidemic effect of $G$. latifolium. The non-significant effect on crude petroleum and $G$. latifolium treatment could be that the mechanism involving lipid metabolism may not have been altered or disturbed by these exposures. It is a fact that biochemical synthesis and/or degradation machinery can only cause observable changes when stimulated (Akpanabiatu et al., 2005).

\section{CONCLUSION}

The values of oxidative and liver function parameters obtained in this study indicates that administration of G. latifolium confers protection against contents of crude oil which induces liver tissue disturbances and/or damage through the regulation of oxidative parameters by the antioxidants present in G. latifolium

\section{REFERENCES}

Aebi H.E. Catalase in vitro. In Methods in enzymatic analysis. Edited by: Bergmeyer HU. Academic press New York; 1984; 3:273.

Alisi C.S., Emejulu, A.A., Alisi, P.N.C., Nwaogu L.A. and Onyema O.O. Decreased cardiovascular risk and resistance to hyperlipedemia-induced hepatic damage in rats by aqueous extract of Urtica dioica. Afri. J. Biochem. Res. 2008; 2(4):102-106.

Allain, C.C. Poon, L.S., Chan, C.S.G., Richmond, W., and Fu, P.U. Enzymatic Determination of Total Serum Cholesterol. Clin. Chem. 1974; 120: 470-475.

Akpanabiatu M.I., Umoh I.B., Udosen E.O., Udoh A.E. and Edet E.E.Rat. Serum Electrolytes, Lipid Profile and Cardiovascular Activity on Nauclea latifolia Leaf Extract Administration. Indian J. Clin. Biochem, 2005; 20 (2) 29-34

Braide, A.S., Adegoke, O.A., and Bamigbowu, E.O. Effects of Cassava Based Diet on Hepatic Proteins in Albino Rats Fed with Crude Oil Contaminated Diet. J. Appl. Se, Environ. Manage. 2011; 15 (1) 223 229.

Brunzel J.D., Davidson M., Furberg C.D., Goldberry R.B., Howar B.V., Stein J.H. and Witztum J.L. Lipoprotein management in patients with cardiometabolic risk: consensus statement from the American Diabetes Association and American College of Cardiology Foundation. Diabetes Care 2008; 31 (4): 811-22 
Bucolo. G. and Daivd, H. Quantitative Determination of Serum Triglycerides by use of Enzymes. Clin. Chem. 1973; (19): 476-482

Demicheli, V., Quijano, C., Alvarez, B., Radi, R. Inactivation and nitration of human superoxide dismutase (SOD) by fluxes of nitric oxide and superoxide. Free Rad. Biol. Med., 2007; 42, 1359-1368.

Doumas, B.T., Watson, W.A. and Biggs, H.G. Albumin standards and the measurement of serum albumin with bomocresol green. Clin. Chim. Acta, 1971; 31, 87-96

Duncan D.B. Multiple range and multiple $\mathrm{F}$ test. Biomet. 1955;11: 1-10.

Fetzer J.C. The Chemistry and Analysis of the Large Polycyclic Aromatic Hydrocarbons. New York: Wiley. 2000.

Fossati, P. and Prencipe, L. Serum Triglycerides Determined Colorimetrically with an Enzyme that Produces Hydrogen Peroxide. Clin.

Chem. 1982; (28): 2077-2080

Halliwell, B., Gutteride, J.M.C. and Cross, E.C. Free radicals, antioxidants and human disease, where are we? Journal of Laboratory Clinical Medicine. 1992; 119:598-602.

King, K.J. and Wootton, I.D.P. Microanalysis in medical Biochemistry, 1959; 14

Ko K.M., I.S.P., Poon, M.K.T., Wu, S.S., Che, C.T., Ng, K.H. Effect of lignin enriched Fructus schisandrae extract on hepatic glutathione status in rats: protection against carbon tetrachloride toxicity. Planta Medica, 1995; 61,134-7.

Lopes-Virella, M.F. Estimation of High density lipoprotein. Clin. Chem. 1977;23:882.

Mankani K.L., Krishna V., Manjunatha B. K., Vidya S.M., Jagadeesh Singh S.D., Manohara Y.N., Anees-Ur R. Avinash KR. Avinash KR. Evaluation of hepatoprotective activity of stem bark of Pterocarpus marsupium Roxb. Indian Journal of Pharmacology, 2005;37 (3): 165-168

Mukherjee, P.K. Plant products with hypercholesterolemic potentials. In: Taylor, Steve L. (Ed.), Advance in Food and Nutrition Research, 47. Elsevier Science, USA, 2003; 277-338.

Nelson, D.L and Cox, M.M. Lehniger Principles of Biochemistry (4th ed.). W.H Freeman and company Publication, New York, 2005; 716-817.

Nwachukwu N. and Ibeh C. Influence of diets formulated with two indigenous spices on serum lipids and liver enzymes in albino rats. Pak. J. Nutr. 2009; 8 (1)

Okafor, J.C. Horticultural promising indigenous wild plant species of the Nigerian forest zone. Acta Horti. 1993; 123:165-176.

Paglia, D.E. and. Valentine W.N. Studies on the quantitative and qualitative characterization of erythrocyte glutathione peroxidase. J. Lab. Clin. Med.1967; 70, 158-169;
Patrick-Anyanwu, K.C., Onyemaenu, C.C., Wegwu, M.O. and Ayalogu, E.O. Hepatotoxic and Nephrotoxic Effects of Kerosene and Petrol - Contaminated Diets in Wistar Albino Rats. Journal of Environmental Toxicology 2011;5 (1): 49-57.

Reitman, S., Reitman S and Frankel S. A. colorimetric determination of serum glutamic oxalo-acetatic and glutamic pyruvic transaminase. Am. J. Clin. Pathol.1957; 28: 56-63

Rohman N., Dosemeci., Li G.L., Bechtold W.E. and Manti G.E Heamatoxicity among Chinese workers heavily exposed to Benzene. Am. J. Ind. Med. 1996;29:236-246.

Rosalinda G., José L. A., Manuel P., Oscar P. V., Carmen J. S. and Patricia Y. Oxidative Stress Modulation by Rosmarinus officinalis in $\mathrm{CCl}_{4}$-induced Liver Cirrhosis, Phytotherapy Research, Published online in Wiley InterScience (www.interscience.wiley.com) 2009;DOI: 10.1002/ptr.2997.

Sunmonu TO. and Oloyede OB, Changes in liver enzyme activities in African catfish (Clarias gariepinus) exposed to crude oil. Asian Fisheries Sci. 2006;19: 104-109.

Sunmonu, T.O. and Oloyede, O.B. Changes in Rat Liver Enzyme Activities Following Consumption of Crude Oil Contaminated Catfish (Clarias Gariephus). Journal of Applied Biosciences 2009;13:720725 .

Thabrew, M.I., Joice, P.D., Rajatissa, W. (1987). A comparative study of the efficacy of Pavetta indica and Osbeckia octandra in the treatment of liver dysfunction. Planta Medica, 53, 239-41.

Tietz, N.W. Clinical guide to laboratory tests. $3^{\text {rd }}$ Edition. WB Saunders Company. Philadelphia, PA.; 1995; 518519

Tsala D. E., Penlab B.V., Nnanga N., Mendimi N. J. Kouamouo J. and Dimo T. Protective activity of the stem bark methanol extract of alafia multiflora against carbon tetrachloride-induced hepatotoxicity in rats. International Journal of Pharmaceutical Sciences Review and Research, 2010; 3 (2) 157-163

Wallin, B., Rosengren, B., Shertzer, H.G and Cameyo, G. Lipoprotein oxidation and measurement of TBARS formation in a single microlitre peate; its use for evaluation of antioxidants. Anal. Biochem. 1993; 208: 10 - 15

Wilson P.W. Agostino R.B., Levy D., Belanger, A.M., Silbershartz H. and Kannel W.B. Predictions of coronary heart disease using risk factor categories. Circulation 1998; 97:1837-1847.

Xin, Z., Waterman, D.F., Henken, R.M. and Harmon, R.J. Effects of Copper Status on neutrophil function, superoxide dismutase and copper distribution in stress. J. Diary Sci. 1991; 74: 3078

Zhejiag, J. Chemical composition and antibacterial activity of Gongronema latifolium. Universal sci. 2007; 8(5):352-358. 